Ann. Génét. Sél. anim., I974, 6 (2), 267-274.

\title{
GENETIC AND PHENOTYPIC PARAMETERS OF BODY TEMPERATURE AND RESPIRATION RATE IN FAYOUMI CHICKS
}

\author{
A. OBEIDAH, A. MOSTAGEER and M. M. SHAFIE \\ Animal Breeding Department, \\ Faculty of Agriculture, Cairo University \\ Giza (Egypt)
}

\section{SUMMARY}

Heritability values for morning and afternoon body temperature and respiration rate were estimated in Fayoumi chicks at hatching and at the ages of I, 2 and 3 months. The numbers of chicks used in the four ages were repectively I424, 959, 64I and 453. The highest $h^{2}$ value of surviving chicks for body temperature was about 0.15 , which occurred at two months of age, Estimates of $h^{2}$ for respiration rate were generally higher than those of body temperature, and for surviving chicks, the highest $h^{2}$ value of 0.25 occurred at $I$ and 2 months of age.

\section{INTRODUC'TION}

The fact that different breeds of chicken differ in their body temperature (HILlERMAN and Wilson, I955; Kamar and KHALIFA, I964; and LAMOREUX and HUTT, I939) and differ also in the response of body temperature to air temperature and relative humidity (FOX, I95 ; LEE et al., I945; and YEATES et al., I94I) would suggest genetic differences between breeds with respect to these characters. In fact such differences were used by HUTT and CRAWFORD (I960) in selecting for high and low body temperatures. Respiration rate is also a character which has its significant role in the heat tolerance mechanism and the stabilization of body temperature in birds.

This work is the first part of some genetic studies on heat tolerance in Fayoumi, a native breed of chicken. It deals with the heritabilities of body temperature and respiration rate of chicks up to three months of age, together with body weight, a production characteristic. 


\section{MATERIAL AND METHODS}

Out of five batches of chicks hatching during December and January, a total number of 1424 unsexed one-day-old Fayoumi chicks was used for this study. Chicks were reared in floor brooders till three months of age under the normal managerial conditions of the Poultry Breeding Farm, Faculty of Agriculture, Cairo University. At hatching and at each of the three ages I, 2 and 3 months chicks were weighed and rectal temperature (in $\mathrm{OF}$ ) and respiration rate were

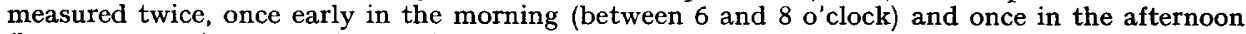
(between 3 and 5 o'clock). Respiration rate per minute was taken as double the actual count measured twice in 30 seconds. Symbols used for traits are $: t$ and $\mathrm{T}$ for morning and afternoon body temperatures respectively, $r$ and $\mathrm{R}$ for the corresponding respiration rates and $w$ for body weight; with subscripts $0,1,2$ and 3 denoting age in months.

The following Table I presents the numbers of sires, dams and offspring used in the four ages studied together with the coefficients of the sire and dam components of variance.

TABLE I

Numbers of sires, dams and offspring

Nombres de mâles, femelles et descendants

\begin{tabular}{c|c|c|c|c|c|c|c}
\hline \hline Age in months & $\begin{array}{c}\text { Survival } \\
\text { group }\end{array}$ & No of sires & No of dams & $\begin{array}{c}N^{\circ} \text { of } \\
\text { offspring }\end{array}$ & $k_{1}\left(^{1}\right)$ & $k_{2}\left({ }^{1}\right)$ & $k_{3}\left({ }^{1}\right)$ \\
\hline $\begin{array}{c}0 \\
\text { (hatch) }\end{array}$ & A & 10 & 95 & 1424 & 14.66 & 17.55 & 140.22 \\
1 & B & 10 & 92 & 959 & 10.12 & 12.68 & 94.08 \\
2 & C & 10 & 90 & 641 & 6.88 & 8.90 & 62.98 \\
3 & D & 10 & 87 & 453 & 5.04 & 6.36 & 44.93 \\
\hline
\end{tabular}

(1) $k_{1}=$ the coefficient of the dam component of variance $\left(\sigma_{d}^{2}\right)$ in the MS between dams/sires, $k_{2}=$ the coefficient of $\sigma_{a}^{2}$ in the MS between sires, and

$k_{3}=$ the coefficient of the sire component of variance in the MS between sires.

It will be noted that the number of chicks measured decreased drastically by age. This is not due to a very high mortality rate, which, however, reached the value of $23 \mathrm{p}$. 100 by the end of the experiment. But the numbers measured were those left, for this particular experiment, randomly chosen from the survivals at any particular age. However, the term " survivals " will be used to denote chicks measured at older ages.

Data were corrected for hatch effect before performing the ordinary hierarchical analyses of variance. Genetic variances $\left(\sigma_{y}^{2}\right)$ were taken as double the sum of the sire and the dam components of variance. Heritabilities $\left(h^{2}\right)$ were then taken as $\sigma_{g} / \sigma_{p}^{2} ; \sigma_{p}^{2}$ being the phenotypic variance. Heritability values (beside the other different parameters) for traits measured at earlier ages, were again recalculated using the earlier performances of survivals to later ages. Thus, for instance, $h^{2}$ for $t_{0}$ had four estimates using the performances of the four survival groups, while $h^{2}$ for $t_{1}$ had only three estimates. A second subscript (A, B, C and D) will be added to denote the survival group; $T_{2} D$ will be the afternoon body temperature $(T)$ at the second month of age (2) of the 453 chicks that " survived " till three months of age (survival group D). 


\section{RESULTS AND DISCUSSION}

\section{I. - Body weight}

Table 2 shows the means, $\sigma_{p}^{\mathbf{2}}, \sigma_{g}^{2}$ and $h^{2}$ of body weight in the four ages. Figures on diagonal represent the values measured on chicks at a certain age, preceding figures on the same line represent the comparable values of the same chicks (only) in the earlier ages.

\section{TABLE 2}

Means, phenotypic variances, genetic variances and heritability values of body weight

Moyennes, variances phénotypiques,

variances génétiques et valeurs de l'héritabilité du poids corporel

\begin{tabular}{|c|c|c|c|c|}
\hline Survival Group & $w_{0}$ & $w_{1}$ & $w_{2}$ & $w_{3}$ \\
\hline & & a) $M$ & (gm) & \\
\hline A & 28.85 & & & \\
\hline $\mathrm{B}$ & 29.02 & 139.77 & & \\
\hline $\mathrm{C}$ & 28.63 & 144.91 & $30 \div .41$ & \\
\hline \multirow[t]{2}{*}{$\mathrm{D}$} & 28.57 & 148.78 & 311.44 & 462.38 \\
\hline & \multicolumn{4}{|c|}{ b) Phenotypic variances } \\
\hline A & 8.07 & & & \\
\hline B & 8.16 & 1505 & & \\
\hline $\mathrm{C}$ & 8.76 & 1116 & 5682 & \\
\hline \multirow[t]{2}{*}{$\mathrm{D}$} & 8.38 & 1100 & 5074 & 14434 \\
\hline & \multicolumn{4}{|c|}{ c) Genetic variances } \\
\hline A & 6.76 & & & \\
\hline B & 7.02 & 270 & & \\
\hline $\mathrm{C}$ & 6.92 & 467 & 1711 & \\
\hline \multirow[t]{2}{*}{$\mathrm{D}$} & 7.04 & 463 & 1756 & 3388 \\
\hline & \multicolumn{4}{|c|}{ d) Heritabilities } \\
\hline A & $\begin{array}{r}0.837 \\
\pm 0.088\end{array}$ & & & \\
\hline B & $\begin{array}{r}0.861 \\
\pm 0.093\end{array}$ & $\begin{array}{r}0.180 \\
\pm 0.068\end{array}$ & & \\
\hline $\mathrm{C}$ & $\begin{array}{r}0.789 \\
+\quad 0.111\end{array}$ & $\begin{array}{r}0.419 \\
+\quad 0.120\end{array}$ & $\begin{array}{r}0.301 \\
+\quad 0.089\end{array}$ & \\
\hline & 0.840 & 0.421 & 0.346 & 0.235 \\
\hline D & \pm 0.128 & \pm 0.136 & \pm 0.114 & \pm 0.100 \\
\hline
\end{tabular}


Comparing the hatching weight $\left(w_{0}\right)$ of the four survival groups, it can be concluded that the three groups $B, C$ and $D$ represent random samples of the original group $A$ with respect to this character, since all have almost the same mean. This conclusion is supported by the fact that the genetic (and phenotypic) variances showed almost the same magnitude in the four groups of chicks. A similar conclusion could in fact be drawn with respect to $w_{1}$ when we compare means only, but the amount of genetic and phenotypic variances would not support this conclusion. For there it is clear that the groups which survived till the second and the third month of age, both, had- beside slightly higher means- higher genetic and lower phenotypic variability. But with regard to $w_{2}$ it can be seen that the means, $\sigma_{g}^{2}$ and $\sigma_{2}$ are not much different in $w_{2} \mathrm{C}$ and $w_{2} \mathrm{D}$.

With respect to the heritability values, very high estimates are obtained for $w_{0}$ in the four survival groups (in the order of 0.8 ). This is not unexpected and is explained usually by the presence of maternal effects. Other estimates of $h^{2}$ of body weight at different ages are not different from those obtained on the Fayoumi (see Ezzeldin, I970). Characters $w_{1 \mathrm{C}}$ and $w_{1 \mathrm{D}}$ showed higher heritability values compared to $w_{1 \mathrm{~B}}$, as would be expected from the previous discussion.

\section{II. - Body temperature}

In comparing the morning body temperature $\left(t_{0}\right)$ of one-day-old chicks (which would give the picture of the basal condition of the body before the day activity), small increases can be observed between the means of the four survival groups (table $3 a$ ). This is connected with a gradual decrease in phenotypic variance and a very marked increase in genetic variance. The amount of genetic variance, however, is very small indeed, being 0.055 in group $A$ and 0.203 in group D. The heritability values of this character, therefore, were higher in groups surviving to older ages, reaching the maximum value of $0 . \mathrm{I} 8 \mathrm{I}$ in $t_{\mathrm{OD}}$.

A similar picture can also be drawn with respect to the afternoon body temperature of the one-day-old chicks $\left(\mathrm{T}_{0}\right)$. However, the values of $\sigma_{p}^{2}$ and $\sigma_{g}^{2}$ of $\mathrm{T}_{0}$ were always lower than the comparable values of $t_{0}$ in the four survival groups, and the heritability values of $\mathrm{T}_{\mathbf{0}}$ are all lower than the corresponding values of $t_{0}$ of the same survival groups. It may be also noted that, apart from the two equal mean values of $t_{3} \mathrm{D}$ and $\mathrm{T}_{3 \mathrm{D}}$, all the $\mathrm{T}$ means are higher than the corresponding $t$ values measured on the same chicks the same morning.

The morning body temperature of the one-month-old chicks $\left(t_{1}\right)$ showed almost the same mean for the three groups of survivals, which was markedly higher than the comparable $t_{0}$. It is clear that morning body temperature increased about $2.5^{\circ} \mathrm{F}$ after one month from hatching, and stayed constant thereafter at about ro6.8 $\mathrm{F}$. It seems that this rise in body temperature occurs earlier, at about 4-ro days after hatching (FREEMAN, I97I ; LAMOREUX and HUTT, I939). The genetic and phenotypic variances, however, showed different trends.

The phenotypic variance $\sigma_{p}$ of the morning body temperature increased drastically from hatch to one month of age. Its value was about $\mathrm{I} .5$ for $t_{\mathbf{0 A}}$ and increased to more than 34 in $t_{1}$ B. This observation may be readily explained by the fact that chicks at hatching are all still poikilotherms, influenced highly by the incubator and the brooder temperatures, and thus showing small amounts of observed variance 
in body temperature $\left(t_{0}\right.$ and $\left.T_{0}\right)$ between chicks. However, another sudden increase in phenotypic variance occurred also at three months of age $\left(\sigma_{p}^{2}\right.$ of $t_{3 \mathrm{D}}$ and $\mathrm{T}_{3 \mathrm{D}}$ were more than IOO). One may guess that the brooder temperature imposed still some restrictions on phenotypic variability in body temperature between individuals in the earlier ages of one and two months. At the age of three months, however, chicks were better feathered and such restrictions are expected then to be much less. The genetic variance of $t$ showed negative values in the two cases $t_{1 \mathrm{~B}}$ and $t_{3} \mathrm{D}$. Considerable $\sigma_{g}$ values occurred in two cases only; namely $t_{1} \mathrm{c}$ and $t_{2} \mathrm{c}$. The heritability in these last two cases reached the values of 0.136 and 0.145 , respectively. It seems then that the only significant heritability value with respect to morning

\section{TABLE 3}

Means, phenotypic variances, genetic variances and heritability values of morning and afternoon rectal temperature

Moyennes, variances phénotypiques, variances génétiques et valeurs de l'héritabilité de la température rectale et post-méridienne

\begin{tabular}{|c|c|c|c|c|c|c|c|c|}
\hline $\begin{array}{c}\text { Survival } \\
\text { Group }\end{array}$ & $t_{0}$ & $\mathrm{~T}_{\mathbf{0}}$ & $t_{1}$ & $T_{1}$ & $t_{2}$ & $\mathrm{~T}_{2}$ & $t_{3}$ & $\mathbf{T}_{3}$ \\
\hline & \multicolumn{8}{|c|}{ a) Means ( $\left.{ }^{\circ} \mathrm{F}\right)$} \\
\hline A & 104.29 & 104.81 & & & & & & \\
\hline B & 104.36 & 104.93 & 106.82 & 107.34 & & & & \\
\hline $\mathrm{C}$ & 104.53 & 105.03 & 106.86 & 107.03 & 106.83 & 107.33 & & \\
\hline \multirow[t]{2}{*}{$\mathrm{D}$} & 104.50 & 105.02 & 106.74 & 106.94 & 106.81 & 107.24 & 106.82 & 106.82 \\
\hline & \multicolumn{8}{|c|}{ b) Phenotypic variances } \\
\hline A & 1.49 & 1.17 & & & V & & & \\
\hline B & 1.32 & 0.99 & 34.19 & 68.26 & & & & \\
\hline C & 1.16 & 0.93 & 36.39 & 36.61 & 36.17 & 36.45 & & \\
\hline \multirow[t]{2}{*}{$\mathrm{D}$} & 1.12 & 0.91 & 50.96 & 51.30 & 50.73 & 51.24 & 100.83 & 101.42 \\
\hline & \multicolumn{8}{|c|}{ c) Genetic variances } \\
\hline A & 0.055 & 0.050 & & & & & & \\
\hline B & 0.107 & 0.036 & -0.153 & -3.083 & & & & \\
\hline $\mathrm{C}$ & 0.151 & 0.075 & 4.938 & 4.769 & 5.232 & 5.498 & & \\
\hline \multirow[t]{2}{*}{$\mathrm{D}$} & 0.203 & 0.090 & 1.588 & 1.310 & 1.910 & 2.605 & -4.206 & -4.945 \\
\hline & \multicolumn{8}{|c|}{ d) Heritabilities } \\
\hline A & $\begin{array}{r}0.037 \\
\pm \quad 0.025\end{array}$ & $\begin{array}{r}0.043 \\
+\quad 0.027\end{array}$ & & & & & & \\
\hline B & $\begin{array}{r}0.082 \\
\pm 0.041\end{array}$ & $\begin{array}{r}0.036 \\
\pm \quad 0.035\end{array}$ & $\begin{array}{r}-0.004 \\
\pm 0.029\end{array}$ & $\begin{array}{r}-0.045 \\
\pm 0.024\end{array}$ & & & & \\
\hline C & 0.131 & 0.080 & 0.136 & 0.130 & 0.145 & 0.151 & & \\
\hline c & \pm 0.063 & \pm 0.056 & \pm 0.064 & \pm 0.063 & \pm 0.065 & \pm 0.065 & & \\
\hline$D$ & 0.181 & 0.099 & 0.031 & 0.026 & 0.038 & 0.051 & -0.042 & -0.049 \\
\hline D & \pm 0.088 & \pm 0.079 & \pm 0.069 & \pm 0.069 & \pm 0.071 & \pm 0.072 & \pm 0.060 & \pm 0.103 \\
\hline
\end{tabular}


body temperature, calculated on all chicks measured at a certain age, is that of $t_{2 \mathrm{c}}\left(h^{2}=0.145\right)$. A similar picture can be observed also with respect to the afternoon body temperature. Body temperature, it seems, being a character of fitness, may differ in different breeds, but has low genetic variance and low heritability within breeds

\section{III. - Respiration rate}

Means, variances, and heritabilities of respiration rate are presented in table 4 . It can be easily observed that the groups surviving to older ages have slightly higher means at hatching. This was accompanied by an obvious decrease in phenotypic

\section{TABLE 4}

Means, phenotypic variances, genetic variances and heritability values of morning and afternoon respiration rates

Moyennes, variances phénotypiques, variances génétiques et valeur de l'héritabilité du rythme respiratoive matinal et post-méridien

\begin{tabular}{|c|c|c|c|c|c|c|c|c|}
\hline $\begin{array}{l}\text { Survival } \\
\text { Group }\end{array}$ & $r_{0}$ & $\mathrm{R}_{\mathbf{0}}$ & $r_{1}$ & $\mathrm{R}_{1}$ & $r_{2}$ & $\mathrm{R}_{2}$ & $r_{3}$ & $\mathrm{R}_{3}$ \\
\hline & \multicolumn{8}{|c|}{ a) Means } \\
\hline A & 88.18 & 88.28 & & & & & & \\
\hline $\mathrm{B}$ & 88.76 & 87.10 & 82.82 & 83.76 & & & & \\
\hline $\mathrm{C}$ & 89.64 & 87.86 & 82.70 & 84.18 & 64.62 & 68.02 & & \\
\hline \multirow[t]{2}{*}{$\mathrm{D}$} & 88.94 & 87.90 & 82.28 & 83.86 & 64.94 & 68.24 & 58.94 & 59.92 \\
\hline & \multicolumn{8}{|c|}{ b) Phenotypic variances } \\
\hline $\mathrm{A}$ & 59.42 & 72.89 & & & & & & \\
\hline B & 56.42 & 68.42 & 49.44 & 51.05 & & & & \\
\hline $\mathrm{C}$ & 55.52 & 69.22 & 47.96 & 52.06 & 44.83 & 52.25 & & \\
\hline \multirow[t]{2}{*}{$\mathrm{D}$} & 54.16 & 73.04 & 49.60 & 51.50 & 40.92 & 48.40 & 44.69 & 43.41 \\
\hline & \multicolumn{8}{|c|}{ c) Genetic variances } \\
\hline A & 7.34 & 11.97 & & & & & & \\
\hline B & 5.76 & 7.45 & 12.26 & 11.03 & & & & \\
\hline $\mathrm{C}$ & 5.13 & 1.65 & 13.80 & 11.34 & 10.97 & 7.72 & & \\
\hline \multirow[t]{2}{*}{$\mathrm{D}$} & 2.45 & -1.93 & 14.05 & 11.67 & 6.02 & 6.96 & 7.06 & 5.30 \\
\hline & \multicolumn{8}{|c|}{ d) Heritabilities } \\
\hline A & $\begin{array}{r}0.124 \\
+\quad 0.041\end{array}$ & $\begin{array}{r}0.164 \\
+\quad 0.048\end{array}$ & & & & & & \\
\hline B & $\begin{array}{r}0.102 \\
+\quad 0.046\end{array}$ & $\begin{array}{r}0.109 \\
\pm \quad 0.049\end{array}$ & $\begin{array}{r}0.248 \\
+\quad 0.084\end{array}$ & $\begin{array}{r}0.216 \\
+\quad 0.073\end{array}$ & & & & \\
\hline $\mathrm{C}$ & $\begin{array}{r}0.092 \\
+\quad 0.058\end{array}$ & $\begin{array}{r}0.024 \\
+\quad 0.053\end{array}$ & $\begin{array}{r}0.288 \\
+0.103\end{array}$ & $\begin{array}{r}0.218 \\
+\quad 0.087\end{array}$ & $\begin{array}{r}0.245 \\
\pm 0.090\end{array}$ & $\begin{array}{r}0.148 \\
+\quad 0.076\end{array}$ & & \\
\hline $\mathrm{D}$ & $\begin{array}{r}0.045 \\
\pm 0.074\end{array}$ & $\begin{array}{r}0.026 \\
\pm \quad 0.063\end{array}$ & $\begin{array}{r}0.283 \\
+\quad 0.119\end{array}$ & $\begin{array}{r}0.227 \\
\pm \quad 0.104\end{array}$ & $\begin{array}{r}0.147 \\
\pm \quad 0.101\end{array}$ & $\begin{array}{r}0.144 \\
+\quad 0.102\end{array}$ & $\begin{array}{r}0.158 \\
+\quad 0.059\end{array}$ & $\begin{array}{r}0.122 \\
\pm \quad 0.091\end{array}$ \\
\hline
\end{tabular}


variance ( $\sigma_{p}^{2}$ was 59.4 in $r_{0 \mathrm{~A}}$ and 54.2 in $r_{0 \mathrm{D}}$ ) and still by a marked decrease in genetic variance ( $\sigma_{g}^{2}$ was 7.3 in $r_{0 \mathrm{~A}}$ and 2.4 in $r_{0} \mathrm{D}$ ). This resulted in the decrease of heritability values from the significant value of 0.142 in $r_{0 \mathrm{~A}}$ to the insignificant value of 0.045 in $r_{0} \mathrm{D}$.

The means of $\mathrm{R}_{0}$ showed lower values than their corresponding $r_{0}$ values, though the differences are of very small magnitudes, but the phenotypic variances of $R_{0}$ were markedly higher. The genetic variance was equal to about $I_{2}$ in $R_{0 A}$ (resulting in the highly significant heritability of 0.164 ) and decreased drastically in the groups surviving to older ages till it showed the negative value of - r.9 in $R_{0 D}$.

The means of $r$ and $\mathrm{R}$ decreased by the advancement of age, and also, after the initial $r_{0}$ and $R_{0}$ values, the $\mathrm{R}$ means showed higher values than those of $r$ measured on the same chicks the same day. The highest amount of decrease occurred in both $r$ and $\mathrm{R}$ between one and two months of age. The role of respiration becomes less in regulating body temperature as the chick develops more feathers, since feathers increase body insulation. Phenotypic variance, too, decreased gradually by the advancement of age, showing the biggest decrease at one month of age ; values for $\mathrm{R}$ being always higher than the comparable $r$ values till both reached almost the same value at three months of age.

The genetic variances of $r_{1}$, which showed higher values compared to those of $r_{0}$, showed a tendency to increase in groups surviving to older ages. The genetic variance of $R_{1 B}$ was a little bit lower than that of $R_{0 A}$, but the tendency of groups surviving to older ages to have higher $\sigma_{g}^{2}$ is also clear. Thus at the age of one month all $h^{2}$ values of $r_{1}$ and $\mathrm{R}_{1}$ were of high and considerable magnitudes, those of $r_{1}$ being always higher than the comparable $\mathrm{R}_{1}$ values. At two months of age, the heritability value was 0.245 for $r_{2} \mathrm{c}$ and 0.148 for $\mathrm{R}_{2} \mathrm{c}$, and at the third month the estimate of heritability decreased to 0.158 in $r_{3} \mathrm{D}$ and to 0.122 in $\mathrm{R}_{3} \mathrm{D}$.

Reçu pour publication en mai 1974.

\title{
RÉSUMÉ
}

\author{
PARAMÈTRES GÉNÉTIQUES ET PHÉNOTYPIQUES DE LA TEMPÉRATURE \\ CORPORELLE ET DU RYTHME RESPIRATOIRE CHEZ DES POULETS FAYOUMI
}

La valeur de l'héritabilité pour la température du matin et de l'après-midi et le rythme respiratoire a été estimée chez des poussins Fayoumi à l'éclosion et aux âges de 1,2 et 3 mois. Les nombres de poussins utilisés aux quatre âges étaient respectivement I 424, 959, 64I et 453 . La plus grande valeur d'héritabilité des poussins survivants pour la température corporelle était voisine de $0,1_{5}$, correspondant à l'âge de 2 mois. Les estimations de l'héritabilité du rythme respiratoire étaient généralement plus élevées que celles de la température, et, pour les poussins survivants, la valeur la plus élevée, égale à 0,25 , était obtenue à $\mathbf{I}$ et 2 mois d'âge.

\section{REFERENCES}

Ezzeldin Z. A., 1970. A study on the genetic parameters of body weight in the fowl. M. Sc. Thesis, Cairo University.

Fox T. W., r951. Studies on heat tolerance in the domestic fowl. Poult. Sci., 30, 477-483. 
A. OBEIDAH, A. MOSTAGEER, M. M. SHAFIE

Freeman B. M., 197x. Body temperature and thermoregulation. In : Physiology and Biochemistry of the Domestic Fowl : Ed. D. J. Bell and B. M. Freeman, Academic Press.

Hillerman J. P., Wilson W. O., r955. Acclimatization of adult chicken to environmental temperature changes. Amer. J. Physiol., 180, 59I-595.

Hutt F. B., CRAwFord R. O., r96o. On breeding chicks resistant to Pullorum diseas without exposure thereto. Canad. J. Genet. Cytol., 2, 357-370.

Kamar G. A. R., Khalifa M. A. S., I964. The effect of environmental conditions on body temperature of fowl. Br. Poult. Sci., 5, 235-244.

Lamoreux W. F., Hutt F. B., 1939. Variability of body temperature in the normal chick. Poult. Sci., 18, 70-75.

Lee D. H. K., Roninson K. W., Yeates N. T. M., Scott M. I. R., r945. Poultry husbandry in hot climates - Experimental inquiries. Poult. Sci., 24, I95-207.

Yeates N. T. M., LeE D. H. K., Hines H. J. G., I94I. Reactions of domestic fowls to hot atmosphere. Proc. R. Soc., 53, 105-I 28. 